\title{
Hazards caused by natural and anthropogenic changes of catchment area in karst
}

\section{O. Bonacci}

Faculty of Civil Engineering and Architecture, Univ. of Split, 21000 Split, Matice hrvatske str. 15, HR-21000 Split, Croatia

Received: 12 July 2004 - Revised: 6 October 2004 - Accepted: 13 October 2004 - Published: 1 November 2004

Part of Special Issue "Natural and anthropogenic hazards in karst areas"

\begin{abstract}
Determination of the catchment area is the starting point in most hydrological analyses. It serves as a basis for many hydrological and water resources management calculations. The catchment boundaries and areas in karst regions are often fragmented and not accurately known. They can change over time due to natural and anthropogenic causes. Natural and man-made processes cause changes of catchment area on different time and space scales. Human intervention, especially construction of dams and reservoirs, as well as interbasin water transfer through long tunnels and pipelines can introduce instantaneous, definite and hazardous change. This paper presents seven examples of natural and anthropogenic factors which influenced changes of catchment area in the Dinaric karst: 1) Closing of the Obod Estavelle in the Fatničeko polje; 2) Operation of the Zakučac hydroelectric power plant on the Cetina River; 3) Problems caused by Salakovac Reservoir; 4) Catastrophic flooding in the Cetinje Polje; 5) Regulation and canalization of the Trebišnjica River; 6) Building of the underground hydroelectric power plant Ombla; 7) An earthquake in Southern Croatia and Western Herzegovina.
\end{abstract}

\section{Introduction}

Karst is typified by a wide range of closed and few open surface depressions, a well-developed underground drainage system, and strong interaction between circulation of surface water and groundwater. Karstification is primarily a geological characteristic important for water circulation and storage. Generally it is greatest at the surface and decrease with the depth of a karst massif. Karstification is a continuous process, caused by natural and/or anthropogenic interactions, so that even the most precise models and/or approaches are only temporally valid (White, 1988; Ford and Williams, 1989; Bonacci, 2001).

Correspondence to: O. Bonacci

(obonacci@gradst.hr)
Water circulation over and throughout karst terrain significantly differs from that in other types of terrain, primarily due to rapid rates of infiltration and the influence of the solutionaly enlarged underground aquifer, clearly distinguishing it from porous aquifers and other types of fracture aquifers. Karst aquifers are generally continuous (Bonacci and Roje-Bonacci, 2000). However, numerous subsurface morphologic karst features strongly influence the continuity of aquifer, and commonly it does not function as a simple continuum within a catchment. Karst aquifers tend to be highly heterogeneous and anisotropic, although karst characteristics and structures are not totally random.

Conditions for water circulation and storage in karstified medium are strongly dependent on space and time scales being considered, especially in the deep and morphologically complex vadose zone. This zone and the underlying phreatic karst aquifer are two-component system in which the major part of storage is in the form of true groundwater in narrow fissures and the matrix, where diffuse or laminar flow prevails. On the other hand, the majority of the water is transmitted through the karst underground by quick or turbulent flow in solutionaly enlarged conduits. The interaction between these two types of flow is significant and permanent. Natural karstification is a very rapid process with respect to geological time spans. Bakalowicz (1975) and Dreybrodt (1988) show that only a few thousand years are required to develop an integrated karst network. Human-induced changes can accelerate this strongly and dangerously.

A karst catchment and water circulation in it is an extremely sensitive and vulnerable system. Very often natural processes and human activities cause changes of the karst catchment area. The aim of this paper is to provide better understanding of hazards caused by natural and anthropogenic changes of catchment area in karst. 


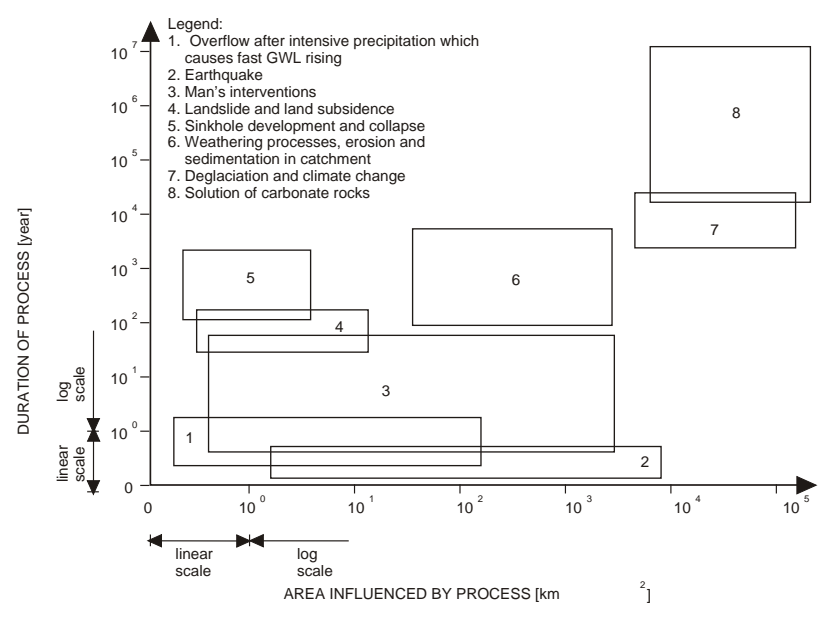

Fig. 1. Time and space scale effects of different factors causing changes of the catchment in karst.

\section{The catchment area in karst and its changes in time and space}

A catchment area (drainage basin or watershed) is a topographically defined area drained by a spring or open channel flow or system of connecting springs and channels such that all outflow is discharged through a single outlet. The determination of the catchment boundaries and the catchment area is a starting point in many hydrological analyses. These are among the essential data which serve as a basis for many calculations for hydrological and water resource management purposes. In karst landscapes this is a difficult and complex task, which very often remains unsolved. Without this information it is not possible, efficiently and precisely, to make a water balance, to protect water from pollution, to manage the water resources, to use hydrological models etc. Generally speaking, the catchment area defined from surface morphology, (i.e. the topographic catchment), will rarely correspond exactly to the karst hydrological drainage basin. The differences between the topographic and hydrological catchments in karst terrain are, as a rule, so large that data about the topographic catchment are useless in practice.

The root causes of problems of karst catchments determination are: 1) Heterogeneous and anisotropic surface and underground morphologic karst forms; 2) Existence of well developed, complex, deep and unknown underground networks of karst conduits, fissures, joints and cracks; 3) Strong interaction between circulation of surface water and groundwater in karst; 4) High and fast oscillations of groundwater levels in karst (often a few hundreds of meters); 5) Strong connection between inflow (swallow-holes) and outflow (karst springs); 6) Small storage capacity of the karst medium and fast groundwater transport through karst conduits; 7) Different aspects of duality of water circulation in karst; 8) Natural endogenous and exogenous processes; 9) Influence of Man's induced structures and activities (dams, reservoirs, water pumping etc.).
When considering determination of catchment area in karst one should bear in mind that the karstification, i.e. the solution and redistribution of surface and subsurface karst features is a continual process, which cannot be stopped and controlled. At any given time, erosion processes can transport sediments underground, sinkholes develop and collapse, landslide and land subsidence occur, there is naturally plugging and unplugging of karst conduits due to tectonic movements, and Man's induced influences can have strong effects on changes of karst catchment areas.

The catchment areas in karst may vary with variation in groundwater levels, i.e. change with time (Bonacci, 1987). There is a specific zone within which the watershed limit is moved towards one or the other spring or towards the streamflow. The position of the watershed line depends upon the groundwater levels which change in time. In some situations, at very high groundwater levels (after heavy rainfall), fossil and inactive channels and springs are activated, causing the interbasin overflow and/or redistribution of the catchment areas (Bonacci, 1995).

Determining of the catchment area of the poljes in karst is an extremely complex task due to fact that a given polje is only part of a wider system. It represents a subsystem in the process of surface, subsurface and underground water flow through the karst massif.

Lowering of the base level, related to tectonic uplift, regression of the sea level massive regional groundwater overpumping or interbasin water transfer cause the development of a new water connections, which result in new karst catchments areas.

Before approximately 19000 years ago the global sea level was about $100 \mathrm{~m}$ lower than now. It represented the erosion basis for many karst areas, so that the coastal spring outlets were at that level. As the sea level rose, new conduits simultaneously formed in the karst together with the new, higher positions of the coastal spring exits. This process is still going on. The direct consequence is gradual change of the catchment areas of coastal karst springs. Change in the position of the coastal karst springs depends upon the local geologic structure. Each actual coastal karst spring has a few conduits. Some of them are active and some are inactive. The main reason for inactivity is existence of clay or some other obstruction (plug) in conduit. Natural (e.g. earthquake) or Man's interventions, which can lead to instantaneous changes of spring catchment area, can remove such plugs.

Tectonic processes, which caused formation of faults and folds, influenced the subdivision of aquifers and establishment of catchment areas in karst terrains. Choppy (1997) states that faults and folds can play various roles for water circulation in karst: a preferential drain, a barrier or no effect.

Human intervention, especially construction of dams and reservoirs as well as interbasin water transfers through long tunnels and pipelines can introduce instantaneous and distinct changes in catchment areas and boundaries. In karst 


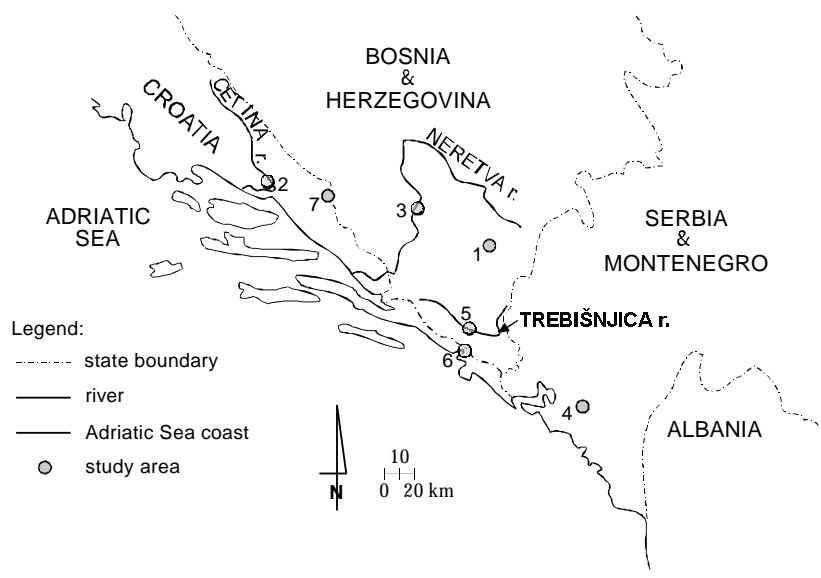

Fig. 2. The map with indicated positions of the seven study areas.

terrains those processes very often are uncontrolled, and result in hazardous consequences.

Under the increased water pressure due to filling a reservoir it is possible to wash out the clay or sand from clogged karst conduits (Breznik, 1998). Dreybrodt and Siemers (1997) warn that dams and reservoirs in karst accelerate evolution of new karst channels below the dam, which can cause serious water losses within its lifetime.

Drastic changes in groundwater level caused by karst water withdrawal from the mines in Hungary led to regional redistribution within the karst aquifer. As the water pumping during the last 40 years exceeded the average natural recharge the groundwater level fell by 30 to $80 \mathrm{~m}$ (Csepregi, 1997).

An attempt to explain time and space scale effects of different factors, which can cause the changes of the catchment area in karst, is given on Fig. 1 (Bonacci, 2002).

\section{Examples of hazards caused by natural factors or hu- man interventions}

Seven examples of the hazards caused by natural and/or human interventions in karst catchments will be described. All occurred in southern part of the Dinaric karst, which belongs to three countries: Croatia, Bosnia and Herzegovina, and Serbia and Montenegro. Figure 2 shows the position of the locations of the examples.

\subsection{Closing of the Obod Estavelle in the Fatničeko Polje}

The strong influence of human intervention on the water circulation in a system of poljes in karst, which caused drastic redistribution of the catchment areas and had hazardous consequence, can be perfectly illustrated by the example of closing the Obod Estavelle in Fatničeko Polje (Site 1, Fig. 2; the locational details are given on Fig. 3). An estavelle is opening in karstic terrain, which acts as a spring during high groundwater levels, and as a swallow-hole during low.

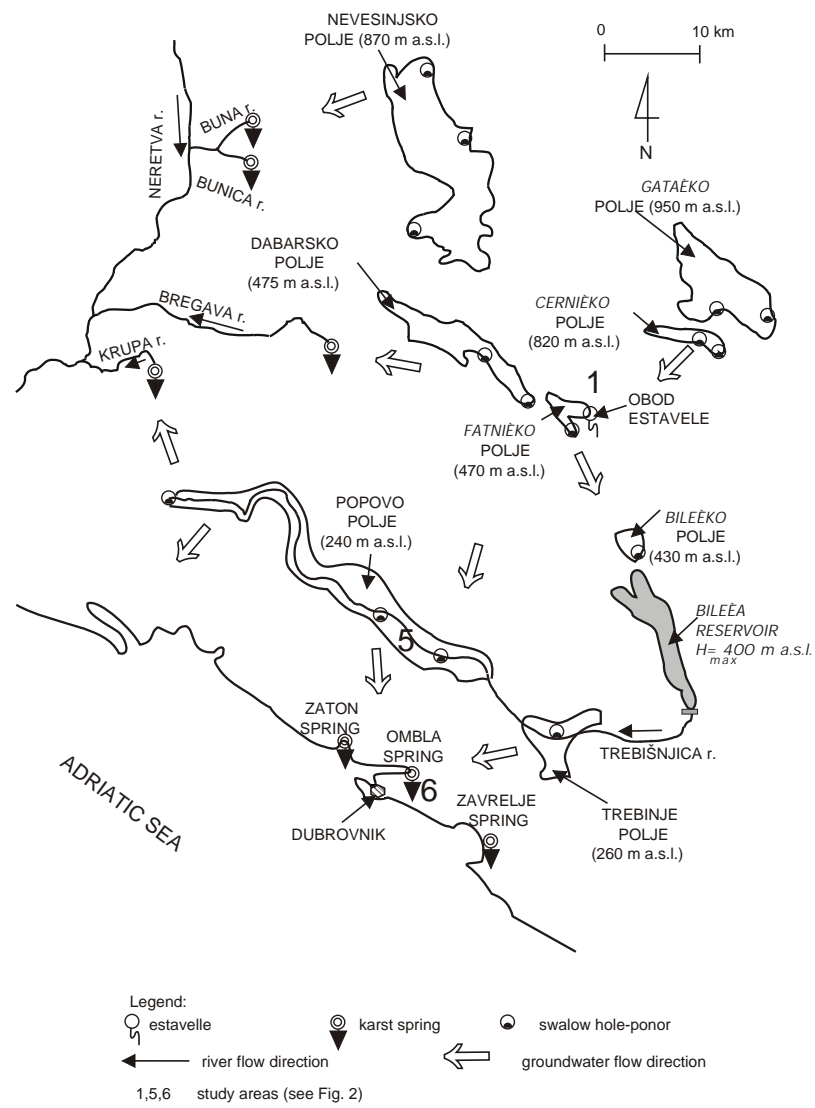

Fig. 3. The map of the South Adriatic coastal karst and the Eastern Herzegovina karst with indication of main karst water phenomena.

The shaft in the estavelle was closed by concrete plug in order to reduce the inflow into the polje and thus to protect it from flooding (Bonacci, 1987). After the estavelle was plugged, an intensive rainfall caused rapid rise of the groundwater levels, up to $120 \mathrm{~m}$ above the elevation of the shaft. An abundance of temporary springs appeared and there was landsliding at levels more than $100 \mathrm{~m}$ above the estavelle. Its closing reduced the inflow into the Fatničeko Polje from 60 to $12 \mathrm{~m}^{3} / \mathrm{s}$. The Polje was only partly protected from the flood but there was heavy damage at the levels high above it where groundwater appeared. This damage called for the urgent destruction of the concrete plug (by blowing it up) in order to restore the previous natural conditions as soon as possible.

3.2 Operation of the Zakučac hydroelectric power plant (HEPP) on the Cetina River

The Cetina River of southern Croatia and western Bosnia and Herzegovina is a typical karst river with the catchment located in the central part of the Dinaric karst region (Bonacci and Roje-Bonacci, 2003). Operation of the Zakučac HEPP caused drastic and, for environment extremely dangerous, changes in the hydrological regime of the downstream portion of the Cetina River over a distance of $40 \mathrm{~km}$. Water is transported into the Zakučac HEPP via two tunnels 


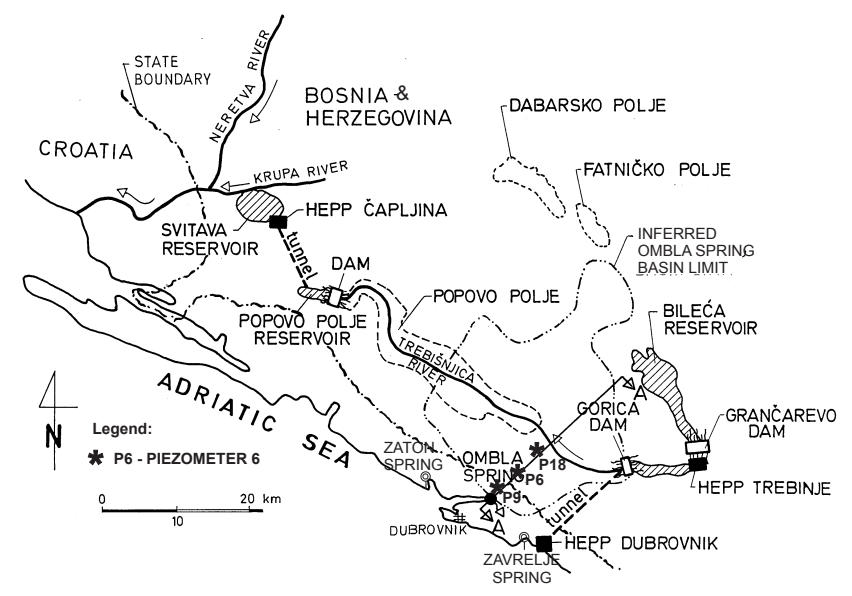

Fig. 4. The map with designated state boundary between Croatia and Bosnia and Herzegovina, reservoirs and HEPP-s of hydrotechnical system constructed on the Trebišnjica River catchment, three piezometers (P9, P6, P18), and karst springs near the Ombla Spring.

totaling $9832 \mathrm{~m}$ length and two pipelines. The first tunnel and pipeline from the Prančevići Reservoir, with discharge of $120 \mathrm{~m}^{3} / \mathrm{s}$ started to operate in 1962, while the second $\left(100 \mathrm{~m}^{3} / \mathrm{s}\right)$ began in 1980 . After the first tunnel and pipeline were brought into function, the mean annual discharges on the Cetina River downstream of the Prančevići Reservoir decreased from about 100 to about $40 \mathrm{~m}^{3} / \mathrm{s}$. After the second pipeline was put into operation, the mean annual discharges dropped to less than $10 \mathrm{~m}^{3} / \mathrm{s}$ or about $10 \%$ of the natural discharge.

In the 1960s, when the volume of ecologically acceptable flow of $8 \mathrm{~m}^{3} / \mathrm{s}$ that had to be released from the Prančevići Reservoir was agreed upon, there was no environmental awareness in this area. In fact, supply of even such a low volume was disregarded. Although environmental awareness altered significantly in the 1980s there were no changes in system management. It is hard to determine the extent and type of the resulting environmental and other damages. The basic problem is the lack of data on the initial state of the ecosystem before the Zakučac HEPP was constructed and put into operation.

\subsection{Problems caused by Salakovac Reservoir operation}

This example demonstrates the negative effects of what is considered to be a successful engineering undertaking in the central part of the Dinaric karst in Bosnia and Herzegovina. Construction of the Salakovac Reservoir on the Neretva River resulted in the flooding of three karst springs on the left bank and three karst springs on the right bank. They now function as swallow-holes (Bonacci and Jelin, 1988). All the water that was lost through them appeared about $1 \mathrm{~km}$ downstream from the dam in a group of springs. Most of these springs were, in natural state, only temporary, and during dry seasons their aggregate discharge was approximately $1 \mathrm{~m}^{3} / \mathrm{s}$.

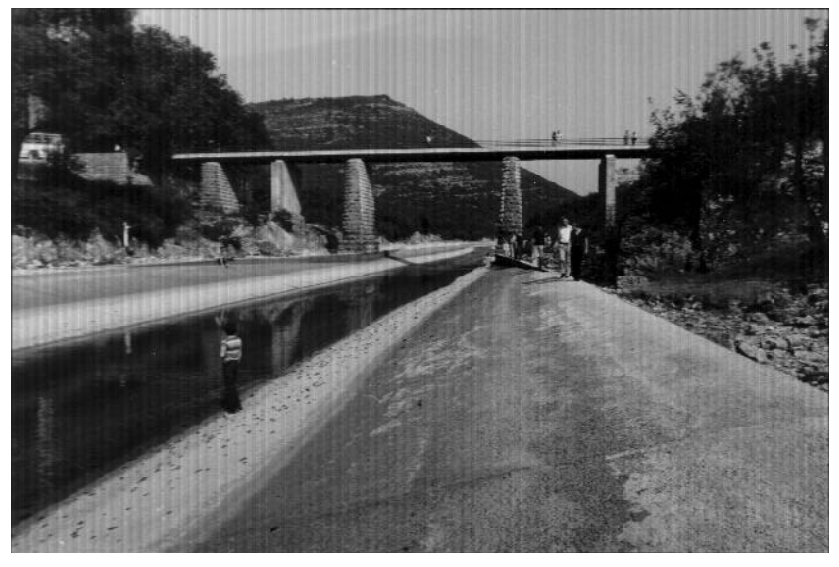

Fig. 5. Photograph of canalization of the Trebišnjica River watercourse by building a concrete canal.

The first filling of the Salakovac Reservoir at the beginning of 1982 gave a dramatic demonstration of how new hydrogeologic conditions can quickly change water circulation in the karst area. The discharge of the downstream springs is now $28 \mathrm{~m}^{3} / \mathrm{s}$ at times of maximum water levels in the reservoir. The mean discharges of the Neretva River at the dam site is $183 \mathrm{~m}^{3} / \mathrm{s}$. Two attempts at remedial works reduced water losses from the reservoir to $22 \mathrm{~m}^{3} / \mathrm{s}$.

On the right side of the Neretva River canyon there is railway tunnel $3239.5 \mathrm{~m}$ in length. In the natural state its bottom was about $37 \mathrm{~m}$ higher than maximum water level of the Neretva River. After the construction of the Salakovac Reservoir, the maximum water level was only $7 \mathrm{~m}$ lower than the tunnel bottom. Every intensive rainfall, which is very frequent in this region, then caused very rapid breakthroughs of water into the tunnel. This situation had never occurred before the Salakovac Reservoir operation. During floods, traffic through the tunnel must be interrupted. The changes of hydrogeological regime caused by rising of the groundwater level of the karst aquifer on the right bank are responsible for this extremely hazardous condition. Very complex and expensive remedial work needs to be done.

\subsection{Catastrophic flood in the Cetinje Polje}

A catastrophic flood in Cetinje Polje between 16 and 20 February 1986 was highly destructive in the town of Cetinje (Serbia and Montenegro). This flood was mostly caused by groundwater discharged from the artificial access tunnel to Cetinje Cave and appearance of new karst springs on the southern margin of the polje (Bošković and Živaljević, 1986; Mijatović, 1987; Bonacci and Živaljević, 1993).

The Cetinje polje is formed by erosion at the altitude of about $650 \mathrm{~m}$ a.s.l. Its size is about $4 \mathrm{~km}^{2}$. The town of Cetinje occupies more than $50 \%$ of the lower part of the polje.

The aggregate precipitation in the Polje catchment between 16-20 February 1986 was $670 \mathrm{~mm}$. At the same time sudden rise in the air temperature, caused by the warm 


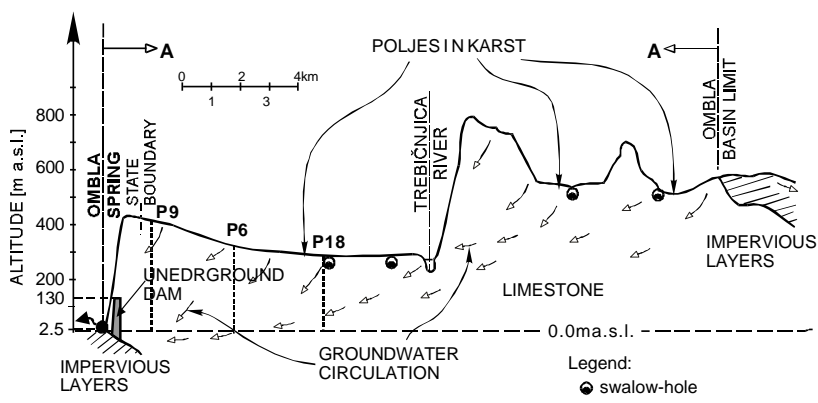

Fig. 6. The cross-section A-A given on the Fig. 4 with designated positions of the Ombla Spring, the HEPP Ombla underground dam (in project), the location of three deep piezometers (P9, P6, P18), the state boundary between Croatia and Bosnia and Herzegovina, the Trebišnjica River, and the inferred Ombla Spring basin limit.

southern wind, led to rapid melting of about $80 \mathrm{~cm}$ thick snow cover in the catchment. Mijatović (1987) considers that karst flooding is generally due to the far smaller capacities of karst drainage systems in the endokarst (deep underground) than in (shallow) epikarst. Bonacci (1987) argues that the protection of the Cetinje town and polje from floods depends upon the capacity of the ponors. From his investigations the maximum capacity of the ponors in the polje is insufficient. Most capacity, situated in the lower part of the polje, and thus within the Cetinje urban area, is about $30 \mathrm{~m}^{3} / \mathrm{s}$ (Bošković and Živaljević, 1986; Mijatović, 1987). The catastrophic flooding drastically emphasized the role of ponors in karst water circulation. Therefore, the swallow capacity of ponors has to be constantly and carefully considered.

The catastrophic flood of February 1986 is typical example of unfortunate coincidence of natural extremes (extremely high precipitation and fast snow melting) and bad human intervention in the karst massif (cutting of the artificial access tunnel to Cetinje Cave in Cetinje Polje).

\subsection{Regulation and canalization of the Trebišnjica River}

Figure 3 represent the map of the South Adriatic coastal karst and the Dinaric karst of Eastern Herzegovina, with indications of main artificial and natural karst phenomena. Figure 4 shows state boundary line between Croatia and Bosnia and Herzegovina, and indicate the reservoirs and HEPPs of a hydroelectrical system constructed in the Trebišnjica River catchment. This area, of about $5000 \mathrm{~km}^{2}$, is part of the deep and bare Dinaric karst. The population is concentrated in several poljes in the karst and in towns along the Adriatic Sea coast.

The Trebišnjica River from the Gorica Dam to the dam at the end of the Popovo Polje is $65 \mathrm{~km}$ in length, and represents a perched stretch of the channel; i.e. its watercourse is $50 \mathrm{~m}$ and more above the groundwater table. Due to this reason there were permanent water losses underground into the karst, and during the summer season the surface flow dried up (Milanović, 1981). The water losses ranged from 40 to $70 \mathrm{~m}^{3} / \mathrm{s}$. In 1978 the $65 \mathrm{~km}$ of the watercourse of the

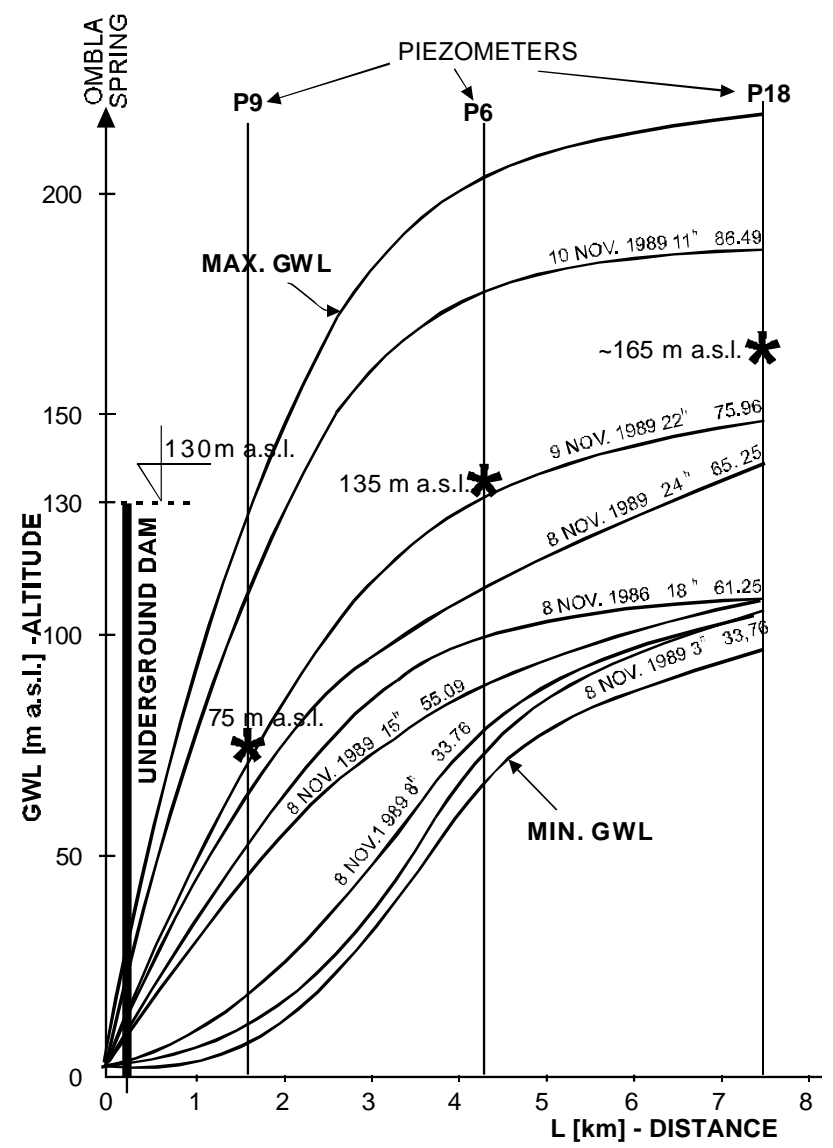

Fig. 7. Ombla catchment groundwater levels on cross-section AA given on Fig. 4 with designated position and elevation of underground dam and altitudes when starts overflow from the Ombla Spring catchment to neighboring karst springs catchments.

Trebišnjica River was regulated and canalized by building a concrete canal with a discharge capacity of $45 \mathrm{~m}^{3} / \mathrm{s}$ (see Fig. 5).

There are very complex karst underground connections between the Trebišnjica River, and the Ombla Spring aquifers (see Figs. 3, 4 and 6). The canalization caused a decrease of the average annual discharge of the Spring from 30 to $22 \mathrm{~m}^{3} / \mathrm{s}$, although significant changes in the minimum and maximum annual discharges were not noticed (Bonacci, 1995). Overall works on the Trebišnjica River catchment and watercourse have strongly altered groundwater circulation and influenced redistribution of the karst catchment areas in the region.

The effects of $65 \mathrm{~km}$ long canalization of the Trebišnjica River, and other human interventions, on the regional environment are not investigated well enough, especially their negative consequences on regional biological diversity and on surviving of endangered, endemic karst species.

\subsection{The Ombla underground HEPP}

There is an underground HEPP construction project planned at Ombla Spring in the vicinity of the city of Dubrovnik. 
Figure 4 shows the locations of Ombla Spring, three deep piezometers (P9, P6 and P18), the state boundary line between Croatia and Bosnia and Herzegovina, Trebišnjica River and inferred Ombla Spring basin limit. Figure 6 shows the cross-section A-A of Fig. 4 with the Ombla HEPP underground dam (projected).

The intention of all the detailed, long lasting and expensive, investigations, which are being conducted within the Ombla HEPP project, is to determine whether or not the idea of forming an underground storage basin by building an underground dam in the hinterland of the Ombla karst Spring can be realized.

The Ombla Spring is an abundant ascending karst spring with an average discharge of $22 \mathrm{~m}^{3} / \mathrm{s}$. The minimum discharge is about $4 \mathrm{~m}^{3} / \mathrm{s}$ and the maximum discharge slightly exceeds $100 \mathrm{~m}^{3} / \mathrm{s}$. Its exact catchment area has not been determined, although numerous investigations and groundwater tracings have been carried out; it is estimated to cover between 800 and $900 \mathrm{~km}^{2}$. Figure 4 shows inferred basin limit in accordance with hydrogeological investigations. There are two permanent karst springs (Zaton and Zavrelje on Figs. 3 and 4) and a few karst springs which dry up. Analyses have shown (Bonacci, 1995; Bonacci and Roje-Bonacci, 2000) that they all are connected to the Ombla Spring catchment. When high groundwater levels of the Ombla aquifer result in discharge exceeding $70 \mathrm{~m}^{3} / \mathrm{s}$ at the Spring, the groundwater overflows into the catchments and aquifers of these other springs.

Figure 7 shows a cross-section from the Ombla Spring through piezometers P9, P6 and P18. This cross-section is designated as A-A on Figs. 4 and 6. Figure 7 also presents some simultaneously measured groundwater levels, outflow discharges at the Ombla Spring and position and elevation of underground dam (the projected elevation is $130 \mathrm{~m}$ a.s.l.). The most important information in all three piezometers is the groundwater levels at which water starts to overflow from the Ombla Spring catchment to neighboring karst springs catchments: $75 \mathrm{~m}$ a.s.1., $135 \mathrm{~m}$ a.s.l., and $165 \mathrm{~m}$ a.s.1. on piezometers $\mathrm{P} 9, \mathrm{P} 6$ and $\mathrm{P} 18$, respectively. This means that construction of so high underground dam will cause continuously overflow of groundwater from the Ombla Spring catchment to other springs. Some intermittent karst springs will become permanent and many other unpredictable and possibly dangerous changes in karst groundwater circulation should be expected. Occurrence of landslides, and dangerous environmental changes are very probable. This dam will change definitely the characteristics of regional karst aquifers and environment. Finally, a further possible problem that should be stressed is that the Ombla HEPP will use groundwater from internationally shared karst aquifer.

\subsection{An earthquake in Southern Croatia and Western Herze- govina}

At 17:19 LT on 23 May 2004 there was an earthquake of $5.5^{\circ}$ on the Richter scale with the epicenter on the boundary between Southern Croatia and Western Herzegovina (Site 7,
Fig. 2). This was a strong earthquake that it caused rapid, but mostly short-lived, changes in the hydrogeological regime of the region. The water levels in all karst rivers in the region quickly decreased by $60-180 \mathrm{~cm}$, and flow from some permanent karst springs dried up. After about $10 \mathrm{~h}$ hydrological situation at the surface returned at the state as it was before the earthquake. Unfortunately there was no information on changes in the karst underground. The same situation occurs after each earthquake in the region. Very often earthquakes cause the collapse of dolines.

\section{Conclusions}

Natural and anthropogenic changes in karst regions frequently cause redistribution in karst catchments, which strongly, suddenly and dangerously affects processes of water circulation at the local or regional scale. Generally these changes are unforeseeable, unexpected and with hazardous consequences. Occurrence of landslides, floods, collapse of dolines, regional water redistribution, drying up of karst springs, conflicts on internationally shared aquifers etc. can be caused. Seven examples are given in this paper. Some of them are caused by natural processes, while others by humans. In the future it is realistic to expect new and greater human interventions in karst areas. All existing structures on karst were built with the same objective, i.e. to improve the water regime and the living conditions in the region. Past experience has shown that many of these works have been suboptimal. The benefit resulting in one area was frequently smaller than damage caused in another area. Caution in seeding, preparation, and fulfillment of them should be extremely high.

Karst catchments and aquifers display the extreme heterogeneity, variability and vulnerability of their hydrologic, hydrogeologic, hydraulic, ecological and other parameters, in time and space. Such complex systems need interdisciplinary co-operation among numerous experts in the broad field of karstology. A first and essential step is to create the aquifer characteristics, the catchment areas and parameters of their water budgets. It should be based on detailed and continuous monitoring of many different hydrogeological, hydrological, geophysical and chemical parameters. To build good and safe structures on karst, and in the same time to identify and protect vulnerable karst environment should be the main aim, of the experts.

Edited by: M. Parise

Reviewed by: D. C. Ford and another referee 


\section{References}

Bakalowicz, M.: Géochimie des eaux karstique et karstification, Annal. de Speleol., 30, 4, 581-589, 1975.

Bonacci, O.: Karst hydrology with special reference to Dinaric karst, Springer Verlag, Berlin, 1987.

Bonacci, O.: Ground water behaviour in karst: example of the Ombla Spring (Croatia), J. of Hydrol., 165, 113-134, 1995.

Bonacci , O.: Analysis of the maximum discharge of karst springs, Hydrogeol. J., 9, 328-338, 2001.

Bonacci, O.: Development of catchment area in karst as a result of natural and anthropological factors, in: Evolution of karst from prekarst to cessation, edited by Grabovšek, F., Inštitut za Raziskovanje Krasa, Postojna, 345-367, 2002.

Bonacci, O. and Jelin, J.: Identification of a karst hydrological system in the Dinaric karst (Yugoslavia), Hydrol. Sci. J., 33, 5, 483497, 1988

Bonacci, O. and Roje-Bonacci, T.: Heterogeneity of hydrologic and hydrogeologic parameters in karst: example from Dinaric karst, Hydrol. Proc., 14, 2423-2438, 2000.

Bonacci, O. and Roje-Bonacci, T.: The influence of hydroelectrical development on the flow regime of the karstic river Cetina, Hydrol. Proc., 17, 1-15, 2003.

Bonacci, O. and Živaljević, R.: Hydrological explanation of the flow in karst: example of the Crnojevića spring, J. of Hydrol., 146, 405-419, 1993
Bošković, M. and Živaljević, R.: Hidrološki osvrt na poplavu Cetinja od 18. do 20.02.1986, (Hydrologic review of the 1986 Cetinje flood), Vodoprivreda, 18, 102-103, 259-264, 1986.

Breznik, M.: Storage reservoirs and deep wells in karst regions, Balkema, Rotterdam, 1998.

Csepregi, A.: Computer simulation of the karstwater table in the Transdanubian mountain ranges, Hungary, in: Karst waters and environmental impacts, edited by Gunay, G. and Johnson, I., Balkema, Rotterdam, 343-352, 1997.

Choppy, J.: La tectonique et la karst, Proc. of $12^{\text {th }}$ Int. Cong. of Speleol., La Chaux de Fonds, 1, 367-368, 1997.

Dreybrodt, W.: Processes in karst systems: physics, chemistry and geology, Springer Verlag, Berlin, 1988.

Dreybrodt, W. and Siemers, J.: Early evolution of karst aquifers in limestone: models on two dimensional percolation clusters. Proc. $12^{\text {th }}$ Int. Cong. of Speleol., La Chaux de Fonds, 2, 75-80, 1997.

Ford, D. C. and Williams, P. W.: Karst geomorphology and hydrology, Unwin Hyman, London, 1989.

Mijatović, B.: Catastrophic flood in the polje of Cetinje in February 1986, a typical example of the environmental impact of karst, Proceed. of the sec. multidisciplinary conf. on sinkholes and the environm. impacts of karst, Orlando, Balkema, Rotterdam, 299303, 1987.

Milanović, P. T.: Karst hydrogeology, Water Resources Publications, Littleton, 1981.

White, W. B.: Geomorphology and hydrogeology of karst terrains, Oxford University Press, Oxford, 1988. 